\title{
Геокриологические исследования на участке Буранный Томторского месторождения
}

\author{
Мисайлов И.Е., научный сотрудник, \\ ИМЗ СО РАН, г. Якутск \\ E-mail: ventura-83@mail.ru \\ Кириллин А.P., \\ ИМЗ СО РАН, г. Якутск \\ E-mail: mouks@ya.ru
}

Научный руководитель: о.2.-м.н., профессор Железняк М.Н.

Изучение особенностей распространения многолетнемерзлых толщ (MМТ) и её параметров является необходимым условием для оценки инженерно-геологических условий при разработке месторождений полезных ископаемых.

Основной целью проводимых исследований является изучение геокриологических условий, в том числе криогенного строения, физико-механических свойств дисперсных пород покровного комплекса, теплофизических свойств основных типов горных пород, а также температурного режима горных пород участка Буранный месторождения Томтор.

Томторское месторождение расположено на северо-востоке Сибирской платформы. Административно относится к Оленекскому улусу Республики Саха (Якутия) и находится в 400км к югу от побережья моря Лаптевых на слабовсхолмленной равнине с абсолютными отметками от 75 до 259 м и относительными превышениями до 80м. (рис.1)

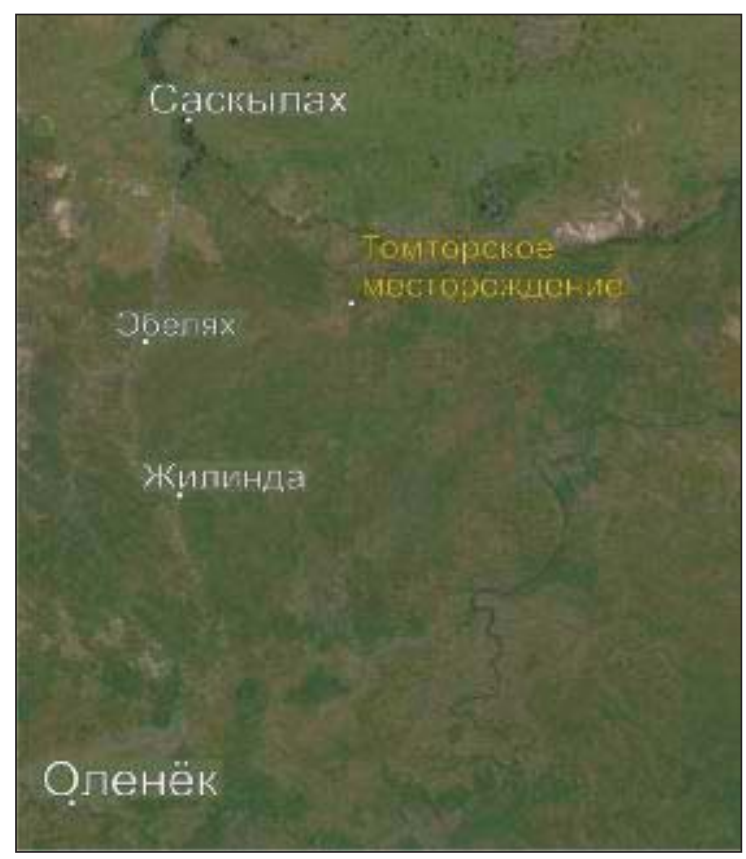

Рис. 1. Обзорная карта 
Климат района резко-континентальный с холодной продолжительной зимой и коротким (2-2,5 месяца) летом. Среднегодовая температура воздуха составляет -14,0 ${ }^{\circ} \mathrm{C}$. Годовое количество осадков колеблется от 200 до 260 мм.

В процессе проведения полевых работ в 2016г., для характеристики особенностей снегопереноса, была проведена снегомерная съемка. Установлено, что в пределах исследуемого участка Буранный мощность снега изменяется от 45 до 71 см, а

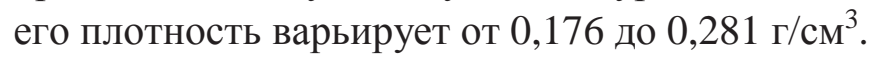

Многолетнемерзлые толщи (ММТ) развиты в пределах Уджинского поднятия северо- востока Анабарской антеклизы до глубины 750 м, непосредственно в пределах месторождения варьируют от 166 до 414 м (Солопанов, 1996г.). Преобладающая мощность сезонно- талого слоя (СТС) составляет 0,7- 1,2 м.

В пределах участка Буранный месторождения Томтор для режимной наблюдательной сети оборудованы шесть скважин, глубиной до 170 м. (рис. 2) После установки в скважинах проведены геотермические замеры.

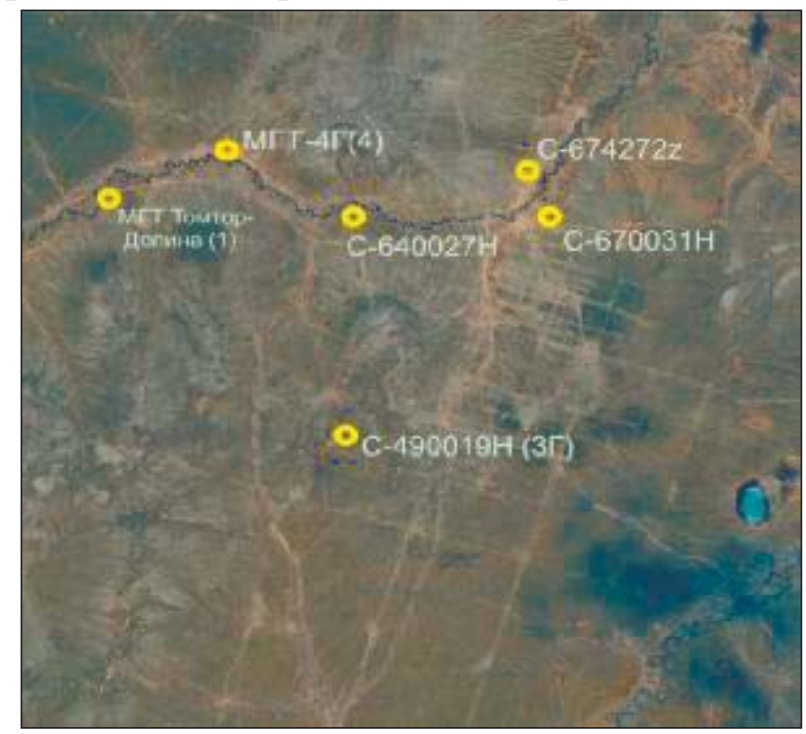

Рис. 2. Местоположение режимных наблюдательных геотермических скважин

По результатам температурных измерений, а также фондовых данных (Солопанов, 1996) установлено, что мощность слоя годовых колебаний температуры составляет 10 м, а температура на его подошве изменяется от $-8,4$ до $-6,1^{\circ} \mathrm{C}$.

Посредством прибора оптического сканирования (Thermal Conductivity Scanning TCS) (рис. 3), а также расчетным путем были проведены исследования теплофизических свойств основных типов горных пород. 

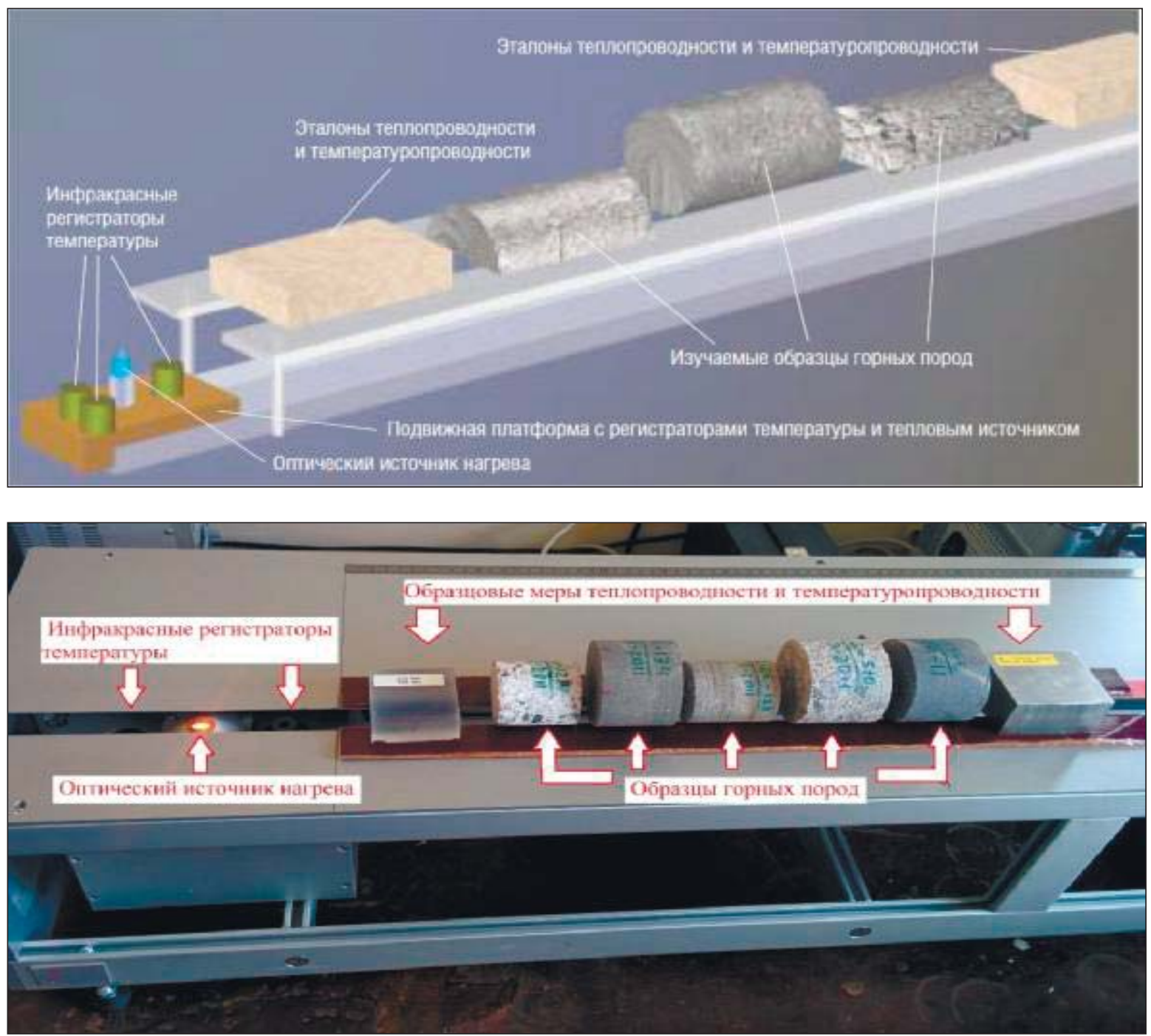

Рис. 3. Принцип метода оптического сканирования.

Теплофизические свойства Анабаро- Оленекской антеклизы характеризуются широким диапазоном их изменений. Так, коэффициент теплопроводности варьирует от 0,71 до 4,07 Вт/(м·К), а объёмный вес скелета - от 1262 до 3428 кг/м², что связано со сложным вещественным составом отдельных метаморфических или метасоматических пород.

Список литературы:

1. Солопанов А.Т., Толстов А.В. Мерзлотно-гидрогеологические условия массива Томтор. Криолитозона и подземные воды Сибири. Часть вторая. Подземные воды и наледи. ИМЗ СО РАН. Якутск, 1996. 